\title{
Systematic analysis of cDNA microarray-based CGH
}

\author{
CHAN HEE PARK ${ }^{1-3}$, HA JIN JEONG ${ }^{1-3}$, YEON HO CHOI ${ }^{1-3}$, SANG CHEOL KIM ${ }^{1}$, \\ HEI CHUL JEONG ${ }^{1,2}$, KYU HYUN PARK ${ }^{1,2}$, GUI YEON LEE ${ }^{1-3}$, TAE SOO KIM ${ }^{1,2}$, SANG WHA YANG ${ }^{1,2}$, \\ SUNG WHAN AHN ${ }^{1}$, YANG SEOK KIM ${ }^{1}$, SUN YOUNG RHA ${ }^{1-3}$ and HYUN CHEOL CHUNG ${ }^{1-3}$ \\ ${ }^{1}$ Cancer Metastasis Research Center, ${ }^{2}$ Yonsei Cancer Center, ${ }^{3}$ Brain Korea 21 Project for Medical Science, \\ Yonsei University College of Medicine, Seoul 120-752, Korea
}

Received August 5, 2005; Accepted September 19, 2005

\begin{abstract}
DNA microarray-based CGH (Microarray-CGH) is a useful technique for detecting genomic aberrations with a high resolution. However, the criteria for determining a genomic alteration have not been determined. We evaluated the genome-wide measurement of copy number of each gene in normal gastric and placenta tissues with both sex-matched, direct and sex-mismatched, indirect designs using 17K cDNA microarray. The results revealed the range of genomic copy number of normal tissues to be \pm 0.3 of the $\log _{2}$ ratio (gain $>0.3$, loss $<-0.3$ ) in the autosomal genes with direct and indirect designs. The copy number at a gene level from the $\mathrm{X}$ chromosomal genes using the direct and indirect sex-mismatched designs was \pm 0.68 of the $\log _{2}$ ratio (amplification $>0.68$, deletion <-0.68). In summary, the suggested method can be used as a guideline for analysis of genomic aberration using a Microarray-CGH in both direct and indirect designs.
\end{abstract}

\section{Introduction}

Conventional comparative genomic hybridization (CGH) is used to analyze chromosome regional variations such as DNA gain, loss, amplification and deletion (1). This technique can provide critical insights concerning the genomic instability and the nature of the sequences that can facilitate a chromosomal rearrangement. However, the low spatial resolution of 5-10 $\mathrm{Mb}$ is a caveat for conventional CGH. A screening method with a higher resolution, a bacterial artificial chromosome (BAC) array-based CGH was developed to reliably detect

Correspondence to: Professor Hyun Cheol Chung, Cancer Metastasis Research Center, Yonsei Cancer Center, Yonsei University College of Medicine, Seoul 120-752, Korea

E-mail: unchung8@yumc.yonsei.ac.kr

Abbreviations: Microarray-CGH, cDNA microarray-based comparative genomic hybridization; FISH, fluorescence in situ hybridization; Cy3, cyanine 3-dUTP; Cy5, cyanine 5-dUTP

Key words: cDNA microarray-based CGH, Microarray-CGH, gain, loss, amplification, deletion, genomic aberration genome-wide deletions and amplifications $(2,3)$. Because the $\mathrm{BAC}$ array-based $\mathrm{CGH}$ still has a limitation on a specific gene level, an innovative technique, a cDNA microarray-based CGH (Microarray-CGH), was developed (4). A genomic alteration detected by Microarray-CGH can easily be translated into both sequence and gene identification, which can provide additional information concerning the complex chromosomal rearrangements and imbalances (5).

Generally, array-based CGH has two types of experimental design for direct and indirect comparisons. The direct design compares a test sample with its paired reference sample $(2,6)$, whereas the indirect design compares a test sample with a common reference, such as normal lymphocyte (7-11) or a normal placenta $(12,13)$. Generally, the lymphocyte and placenta are presumed to be genomically normal and easy to obtain as a reference. However, with the indirect design, considerations must be paid to the organ-specific genomic difference between the test and reference samples, as well as to the sex-specific differences such as a sex-matched $(11,13)$ or sex-mismatched comparison with reference $(5,7)$.

Theoretically, the $\log _{2}$ ratio with single copy change of each gene using Microarray-CGH is supposed to be 1.0. However, experimentally measured single copy change of genes showed wide variations. In a test using the sex chromosomal genes, a $\log _{2}$ ratio range of 0.22-0.28 was suggested for a single copy change at a gene level $(3,4)$. With the indirect design, a $\log _{2}$ ratio range of 0.2-0.6 has been suggested for a single copy change level of gene $(7,8,10,12,14,18-20,22-24)$.

In this study, the optimal $\log _{2}$ ratio of genomic alterations such as gain, loss, amplification and deletion were determined using a Microarray-CGH system with special considerations on an organ-specific genomic difference (indirect design) and a sex-specific genomic difference (direct and indirect design).

\section{Materials and methods}

Tissues and cancer cell lines. Twenty-three normal gastric tissues (11 male and 12 female cases) which located $>10 \mathrm{~cm}$ away from a tumor were obtained from gastric cancer patients who had undergone surgery. The male and female placenta tissues were obtained after a normal delivery. The tissues were procured with informed consent from the patients after the approval of the Institutional Review Board of Yonsei Cancer Center, Yonsei University College of Medicine, Seoul, 
Table I. Designs of experiments for determining genetic alterations of X chromosome located genes.

\begin{tabular}{lccccc}
\hline & \multicolumn{2}{c}{ Direct design } & & \multicolumn{2}{c}{ Indirect design } \\
\cline { 2 - 3 } \cline { 5 - 6 } & $\mathrm{P}(\mathrm{Cy} 3): \mathrm{P}(\mathrm{Cy} 5)$ & $\mathrm{G}(\mathrm{Cy} 3): \mathrm{G}(\mathrm{Cy} 5)$ & & $\begin{array}{c}\text { Sex-matched } \\
\mathrm{P}(\mathrm{Cy} 3): \mathrm{G}(\mathrm{Cy} 5)\end{array}$ & $\begin{array}{c}\text { Sex-mismatched } \\
\mathrm{P}(\mathrm{Cy} 3): \mathrm{G}(\mathrm{Cy} 5)\end{array}$ \\
\hline Sex type & $\mathrm{XX}: \mathrm{XY}$ & $\mathrm{XX}: \mathrm{XY}$ & & $\mathrm{XY}: \mathrm{XY}$ & $\mathrm{XY}: \mathrm{XX}$ \\
$\mathrm{X}$ chromosome change & Deletion & Deletion & & No change & Amplification \\
Sex type & $\mathrm{XY}: \mathrm{XX}$ & $\mathrm{XY}: \mathrm{XX}$ & & $\mathrm{XX}: \mathrm{XX}$ & $\mathrm{XX}: \mathrm{XY}$ \\
$\mathrm{X}$ chromosome change & Amplification & Amplification & & No change & Deletion \\
\hline
\end{tabular}

P, normal placenta tissue; G, normal gastric tissue; $\mathrm{XX}$, female tissue; $\mathrm{XY}$, male tissue.

Korea. Resected tissue samples were immediately frozen into liquid nitrogen and stored at $-80^{\circ} \mathrm{C}$ until further use. One gastric cancer cell line, YCC-16, was established in Yonsei Cancer Center, Yonsei University College of Medicine, Seoul, Korea.

DNA extraction. Fresh frozen tissues (100 mg) and YCC-16 gastric cancer cells were minced and incubated with $400 \mu 1$ of a DNA lysis buffer (10 mM Tris pH 7.6, $10 \mathrm{mM}$ EDTA, $50 \mathrm{mM} \mathrm{NaCl}, 0.2 \% \mathrm{SDS}, 200 \mu \mathrm{g} / \mathrm{ml}$ Proteinase $\mathrm{K}$ ) at $42^{\circ} \mathrm{C}$ for 12-24 h. The incubated products were boiled for $10 \mathrm{~min}$ at $100^{\circ} \mathrm{C}$ to inactivate the enzymatic activity and then treated with the same amount of phenol/chloroform/isoamylalcohol (Gibco-BRL, Gaitherburg, MD, USA). The DNA in the supernatant was precipitated with $100 \%$ ethyl alcohol containing a $1 / 3$ volume of $10 \mathrm{M}$ ammonium acetate and $2 \mu \mathrm{l}$ of glycogen. After rinsing with $70 \%$ ethyl alcohol, the DNA was dried at room temperature and then dissolved in ultra-pure water. The DNA concentrations were determined using a UVspectrophotometer (Hitachi Inc., Tokyo, Japan) and stored at $-20^{\circ} \mathrm{C}$ until needed.

Microarray-CGH. The Microarray-CGH was performed according to the Cancer Metastasis Research Center Yonsei University College of Medicine, Korea (CMRC) protocol (13) in various experimental design (Table I). Briefly, $6 \mu \mathrm{g}$ of the extracted genomic DNA was digested at $37^{\circ} \mathrm{C}$, for $2 \mathrm{~h}$ by DpnII (NEB, Beverly, MA, USA) and cleaned up using a QIAquick PCR purification kit (QIAgen, Dusseldorf, Germany) according to the manufacturer's instructions. Labeling was performed with Cy3-dUTP or Cy5-dUTP, using a Bioprime labeling kit (Invitrogen, CA, USA) and the unincorporated nucleotides were removed using a PCR purification Kit (QIAgen). The eluted probes were then mixed and supplemented with $30 \mu \mathrm{g}$ of Human Cot-1 DNA (GibcoBRL), $20 \mu \mathrm{g}$ of poly-A RNA (Sigma), $100 \mu \mathrm{g}$ of yeast t-RNA (Gibco-BRL), and $288 \mu 1$ of a $1 \mathrm{M}$ TE buffer ( $\mathrm{pH} 8.0$ ). This probe mixture was concentrated using a Microcon-30 (Amicon, Bedford, MA, USA). For the final probe preparation, $15.3 \mu 1$ of $20 \mathrm{X} \mathrm{SSC} \mathrm{(pH} \mathrm{8.0)} \mathrm{and} 2.7 \mu 1$ of $10 \%$ SDS were added to the probe mixture to make a total volume of $90 \mu 1$. The probe was denatured by heating for 2 min at $100^{\circ} \mathrm{C}$ and then applied to the $17 \mathrm{~K}$ human cDNA microarray (CMRC-GenomicTree Co., Korea). The microarray was hybridized at $65^{\circ} \mathrm{C}$ for $16 \mathrm{~h}$ in a hybridization chamber (GenomicTree Co., Korea) with the humidity maintained by 3.5X SSC. After hybridization, the slides were washed for $2-5 \mathrm{~min}$ in $2 \mathrm{X} \mathrm{SSC}$ with $0.1 \%$ SDS, which was followed by $1 \mathrm{X}$ SSC with $0.1 \%$ SDS, $0.2 \mathrm{X}$ SSC. The slides were then rinsed twice with $0.05 \mathrm{X}$ SSC. After washing, the slides were spun dried at $600 \mathrm{rpm}$ for $5 \mathrm{~min}$.

Microarray imaging and analysis. The slides were scanned using a GenePix 4000B scanner (Axon Instruments, Foster City, CA, USA) and the TIFF images were analyzed with GenePix Pro 4.1 software (Axon Instruments). The foreground and background intensities of both $\mathrm{Cy} 3$ and $\mathrm{Cy} 5$ were calculated for each spot and exported into Genepix Array List (GAL) files.

Data pre-processing and normalization. 17K cDNA microarray contained the 15,723 unique genes with 17,664 spots and these unique genes were mapped for their chromosomal location using SOURCE (http://genome-www5.stanford.edu/cgi-bin/ source/sourceSearch) and DAVID (http://apps1.niaid.nih.gov/ david/). In order to obtain accurate results, unfavorable spots were removed according to the following criteria: a) spots with low foreground intensity (foreground/background intensity ratio $<1$ or foreground intensity $<500)$, b) the spots with an unknown chromosomal location, and c) the spots with a different location between SOURCE and DAVID. The transformation of the intensity signal to a ratio was carried out using the $\log _{2}$ red to green ratio $(\mathrm{R} / \mathrm{G})$. In order to correct the differences caused by labeling efficiencies, a within-slide global normalization was applied, which subtracted the median intensity ratio of the $\log _{2}(R / G)$ from the $\log _{2}$-transformed data. The $\log _{2}$ data were linked to the genomic information, such as the gene name, the GeneBank accession number, the number of the chromosomal location, and then mapped onto the position of each chromosome. The genomic aberration patterns were presented using $\mathrm{CGH}$ analyzer and Map Viewer using S-Plus 2000 (CAMVS, CMRC) software.

Determination of the genomic alteration with $\log _{2}$ transformed data. Genomic alterations of a gain or loss of each gene were determined to be greater or lower than the absolute mean \pm standard deviation (SD) of the gene values within the autosome and sex chromosome. With the sex-mismatched designs, the values from the $\mathrm{X}$ chromosomal genes were used to determine an amplification or deletion. The genomic alterations of an 
Table II. Genetic alteration of autosomal and sex chromosomal genes based on experimental design.

\begin{tabular}{|c|c|c|c|c|c|c|c|c|c|c|}
\hline & \multirow[t]{2}{*}{ (Cy5)/(Cy3) } & \multirow[t]{2}{*}{$\begin{array}{c}\text { Autosome } \\
\text { (absolute } \\
\text { mean value) }\end{array}$} & \multicolumn{2}{|c|}{$\begin{array}{l}\text { Sex chromosome } \\
(\text { mean } \pm 1 \mathrm{SD} \\
\left.\log _{2} \text { ratio }\right) \\
\end{array}$} & \multicolumn{3}{|c|}{$\begin{array}{c}\text { Cut-off level of } \\
\text { gene aberration } \\
\text { (absolute mean value) }\end{array}$} & \multicolumn{3}{|c|}{$\begin{array}{c}\text { No. of genes with } \\
\text { single copy change } \\
\left(\log _{2} \text { ratio }>0.68\right) \\
\end{array}$} \\
\hline & & & $\mathrm{X}$ & $\mathrm{Y}$ & $\begin{array}{l}\text { Autosome } \\
(\mathrm{n}=8,923)\end{array}$ & $\begin{array}{c}X \\
(n=233)\end{array}$ & p-value & Autosome & $\mathrm{X}$ & $\mathrm{Y}$ \\
\hline \multirow[t]{4}{*}{ Direct design } & P XX/P XY & 0.30 & 0.72 & -1.32 & \multirow{4}{*}{0.30} & \multirow{4}{*}{0.68} & \multirow{4}{*}{$>0.001$} & 73 & 52 & 5 \\
\hline & P XY/P XX & 0.30 & -0.59 & 0.33 & & & & 46 & 30 & 0 \\
\hline & G XX/G XY & 0.31 & 0.68 & -0.57 & & & & 39 & 3 & 1 \\
\hline & G XY/G XX & 0.29 & -0.69 & 1.23 & & & & 360 & 6 & 3 \\
\hline \multirow[t]{4}{*}{$\begin{array}{l}\text { Indirect design } \\
\text { (experiment no.) }\end{array}$} & G XX/P XY (5) & 0.30 & 0.69 & -1.50 & \multirow[t]{2}{*}{0.30} & \multirow[t]{2}{*}{0.68} & \multirow[t]{2}{*}{$>0.001$} & 18 & 36 & 5 \\
\hline & G XY/P XX (6) & 0.30 & -0.71 & 2.01 & & & & 132 & 71 & 5 \\
\hline & G XX/P XX (6) & 0.29 & 0.32 & -0.32 & \multirow[t]{2}{*}{0.30} & \multirow{2}{*}{0.30} & \multirow[t]{2}{*}{ - } & 36 & 1 & 0 \\
\hline & G XY/P XY (4) & 0.32 & 0.29 & -0.51 & & & & 53 & 0 & 0 \\
\hline
\end{tabular}

P, normal placenta tissue; G, normal gastric tissue; XX, female tissue; XY, male tissue; SD, standard deviation; gain, $\log _{2}$ ratio $>0.3$; $\operatorname{loss}_{1} \log _{2}$ ratio $<-0.3$; amplification, $\log _{2}$ ratio $>0.68$; deletion, $\log _{2}$ ratio $<-0.68$.

amplification or deletion of each gene were determined to be greater or lower than the absolute mean \pm SD of the gene values within the $\mathrm{X}$ chromosome in a sex-mismatched design. Finally, we selected the pseudo-alteration genes in autosomes, which genes showed a consistent genomic alteration pattern regardless of various experimental designs.

Fluorescence in situ hybridization for c-erbB-2 amplification. c-erbB-2 gene status was determined by fluorescence in situ hybridization (FISH). Interphase nuclei of YCC-16 gastric cancer cells were hybridized with red fluorescent-labeled probes. HER-2/neu probe mix was consisted of a mixture of a Spectrum Green fluorophore-labeled- $\alpha$-satellite DNA probe for chromosome 17 and a Spectrum Orange fluorophorelabeled DNA probe for the c-erbB-2 gene locus (17q11.2q12) (Vysis PathVysion ${ }^{\circledR}$ HER-2 DNA Probe Kit; Vysis Inc., Downers Grove, IL, USA). c-erbB-2 and chromosome 17 nuclear signals were counted under a microscope, which yielded the ratio of the copy numbers of the c-erbB-2 gene to chromosome 17 (19).

\section{Results}

Determination of genomic alteration and gene copy number change in Microarray-CGH. After the filtration, 13,808 genes remained, which included 9,161 genes with a known chromosomal location. The 9,161 genes composed of 8,923 autosomal and 238 sex chromosomal genes including $5 \mathrm{Y}$ chromosome located genes and $233 \mathrm{X}$ chromosome located genes.

In order to determine the criteria of the genomic aberration, 25 Microarray-CGH with normal tissue samples including both the direct sex-matched or sex-mismatched designs and the indirect sex-matched or sex-mismatched designs were performed (Table II).
First, 8,923 autosomal genes were evaluated to determine the gain or loss value in a sex-matched design. An absolute mean \pm SD value of autosomal genes was $0.3 \log _{2}$ ratio in 10 indirect sex-matched designs, which was similar to that of the direct designs. Using a total of 14 direct and indirect sexmatched designs, the mean \pm SD value of 8,923 autosomal genes was $0.3 \log _{2}$ ratio. Based on these results, the chromosomal aberration was determined to be $>0.3 \log _{2}$ ratio as a gain or $<-0.3 \log _{2}$ ratio as a loss.

Next, $233 \mathrm{X}$ chromosomal genes were evaluated to determine the criteria of the amplification or deletion in the sex-mismatched designs with the assumption of a single copy change of $\mathrm{X}$ chromosomal genes. Using direct sexmismatched design, the $233 \mathrm{X}$ chromosomal genes showed mean $\log _{2}$ ratios of 0.70 and $-0.67 \log _{2}$ ratio (Fig. 1A). Indirect sex-mismatched experiments showed similar genomic aberration compared to direct sex-mismatched design, 0.69 and $-0.72 \log _{2}$ ratio (Fig. 1B and C). Based on the change in the $\mathrm{X}$ chromosomal genes, the criteria of a copy change at a gene level was determined to be $>0.68 \log _{2}$ ratio as an amplification or $<-0.68 \log _{2}$ ratio as a deletion (Fig. 2).

Distribution of genomic alterations in autosomal and sexchromosomal genes. In the direct design, $89 \%$ of the genes in both the autosomes and sex-chromosomes showed no change in the $\log _{2}$ ratio. However, $11 \%$ of the genes showed genomic alteration patterns $>0.3$ or $<-0.3 \log _{2}$ ratio and $1 \%$ of the genes showed a copy change pattern $>0.68$ or $<-0.68 \log _{2}$ ratio (Fig. 3A and C). In the 11 indirect sex-mismatched designs, the criteria of the autosomal genes were -0.3 to $-0.3 \log _{2}$ ratio and similar to those of the direct sex-mismatched design. Genomic alteration criteria were found in $5.5 \%$ of the genes and $0.4 \%$ of the genes showed a copy number change pattern with $>0.68$ or $<-0.68 \log _{2}$ ratio (Fig. 3B). In contrast, $60 \%$ of 



Figure 1. Distribution of genomic alterations according to genomic location on the $\mathrm{X}$ chromosome. (A) In the sex-mismatched, direct design, most $\mathrm{X}$ chromosomal genes showed $>0.3$ or $<-0.3 \log _{2}$ ratios and average genomic aberration value was $\pm 0.68 \log _{2}$ ratio with placenta $(\mathbf{\Lambda}, \bullet)$ and gastric tissue $(\triangle, \circ)$. (B) X chromosomal genes with sex-mismatched, indirect design showed a genomic aberration patterns $(\mathbf{\Delta}, \bullet)(\mathrm{P}$, placenta tissue; G, gastric tissue; XX, female; XY, male). (C) Sex-matched, indirect design showed no genomic aberration patterns with the average $\log _{2}$ ratio of $0(\triangle, \circ)(P$, placenta tissue; G, gastric tissue; XX, female; XY, male).

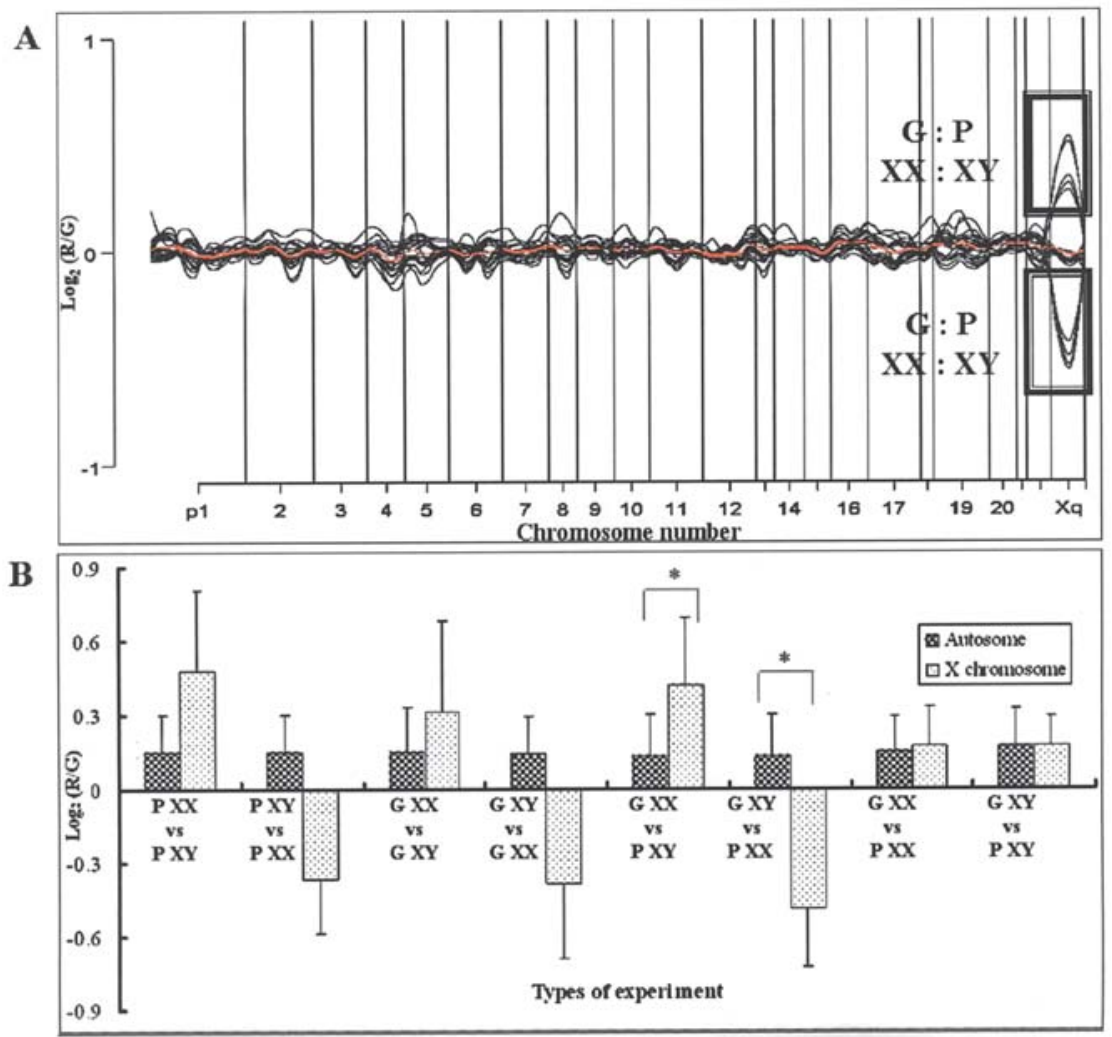

Figure 2. Patterns of the alteration of each gene in all chromosomes using the indirect sex-mismatched design with CAMVS software. (A) Most of the autosomal genes showed no changes with the genomic values between $\log _{2}$ ratio $-0.3-0.3$, whereas most of the sex chromosomal genes showed a level of single copy change (amplification: $\log _{2}$ ratio $>0.68$; deletion: $\log _{2}$ ratio <-0.68) with CAMVS software. The yellow line is a loss curve with 0.2 span. P, placenta tissue; G, gastric tissue; XX, female; XY, male. (B) The various levels of genomic alterations in autosomal and X chromosomal genes based on a different designs. $\mathrm{P}$, placenta tissue; $\mathrm{G}$, gastric tissue; : autosomal genes;, $\mathrm{X}$ chromosomal genes; $\mathrm{XX}$, female; $\mathrm{XY}$, male; ${ }^{*} \mathrm{p}<0.001$. 

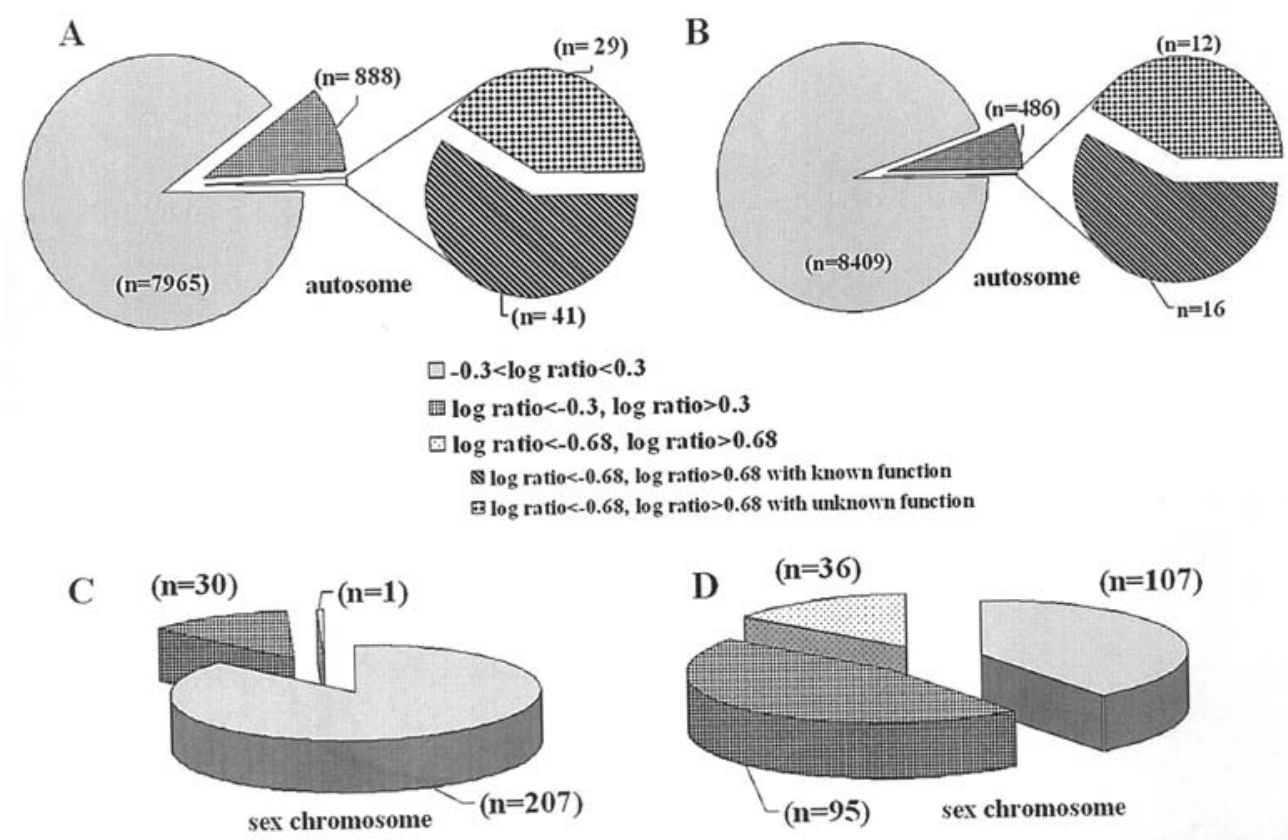

Figure 3. Number of genomic aberration genes in the indirect design. (A) Sex-matched autosomal genes, (B) sex-mismatched autosomal genes, (C) sex-matched $X$ chromosomal genes and (D) sex-mismatched X chromosomal genes. $n$, number of genes; grey, $-0.3<\log _{2}$ ratio $<0.3$; 粗 , $\log _{2}$ ratio $>0.3$ or $\log _{2}$ ratio $<-0.3$; $;$, $\log _{2}$ ratio $>0.68$ or $\log _{2}$ ratio $<-0.68 ; \mathbb{\otimes}$, single copy changed genes with known function; $\bullet$, single copy changed genes with unknown function.

Table III. Genes showing the pseudo-alteration patterns.

\begin{tabular}{lllllc}
\hline \multicolumn{1}{c}{ ID } & \multicolumn{1}{c}{ Name } & Mean \pm SD & Frequency & Cytoband \\
\hline Deletion & AI589117 & ESTs & $-1.04 \pm 0.31$ & 21 & $6 \mathrm{q} 23.3$ \\
& AA149987 & Protease, serine, 16 (thymus) & $-0.82 \pm 0.24$ & 19 & $6 \mathrm{p} 21$ \\
& AA962445 & ESTs & $-0.81 \pm 0.14$ & 19 & $15 \mathrm{q} 22.2$ \\
& AA481486 & ESTs & $-0.74 \pm 0.35$ & 14 & $2 \mathrm{q} 32.3$ \\
& R00859 & Cathepsin K (pycnodysostosis) & $-0.66 \pm 0.15$ & 16 & $1 \mathrm{q} 21$ \\
& AA936514 & Testis specific basic protein & $-0.65 \pm 0.14$ & 14 & $6 \mathrm{p} 21.3$ \\
& AI207203 & ESTs & $-0.61 \pm 0.17$ & 8 & $2 \mathrm{q} 21$ \\
& AI343625 & DKFZP58N2124 protein & $-0.54 \pm 0.16$ & 5 & $11 \mathrm{q} 14$ \\
& AA485140 & HDCMC28P protein & $-0.50 \pm 0.13$ & 5 & $20 \mathrm{p} 12.1$ \\
& AA481052 & Hypothetical protein FLJ20984 & $-0.49 \pm 0.17$ & 3 & $6 \mathrm{q} 25.3$ \\
& AI688757 & Cytochrome c oxidase subunit Vb & $0.76 \pm 0.55$ & 8 & $2 \mathrm{cen}-\mathrm{q} 13$ \\
& AA873479 & EST & $0.65 \pm 0.38$ & 6 & $2 \mathrm{p} 13.1$ \\
& AA872273 & Homo sapiens chromosome 19, BAC & $0.52 \pm 0.19$ & 3 & $19 \mathrm{q} 13.32-\mathrm{q} 13.33$ \\
& R02346 & Small nuclear ribonucleoprotein & $0.52 \pm 0.10$ & 3 & $19 \mathrm{q} 13.3$
\end{tabular}

The genes that showed consistent genetic aberration. Mean, average $\log _{2}$ value with all experiments; SD, standard deviation; frequency, number of amplificated or deleted genes among 25 experiments; cytoband, chromosomal location.

$\mathrm{X}$ chromosomal genes showed a genomic alteration pattern, and among these genes, $15 \%$ of the genes showed a duplicate gene change patterns as expected (Fig. 3D).

Genes with a pseudo-alteration pattern. Fifteen autosomal genes showed consistent copy number change patterns, such as gain or loss, regardless of the experiment design. Among the genes with this type of false copy number change pattern, pseudo-alteration pattern, 10 deleted genes showed an average $\log _{2}$ ratio of -0.49 to -1.04 and 5 amplified genes showed an average $\log _{2}$ ratio of 0.48 to -0.76 . Among these genes, the chromosome 6 open reading frame 198 (GenBank accession number AI589117) gene showed the pseudo-alteration pattern of $84 \%$ frequency with the mean $\log _{2}$ ratio of -0.68 (Table III). 
A

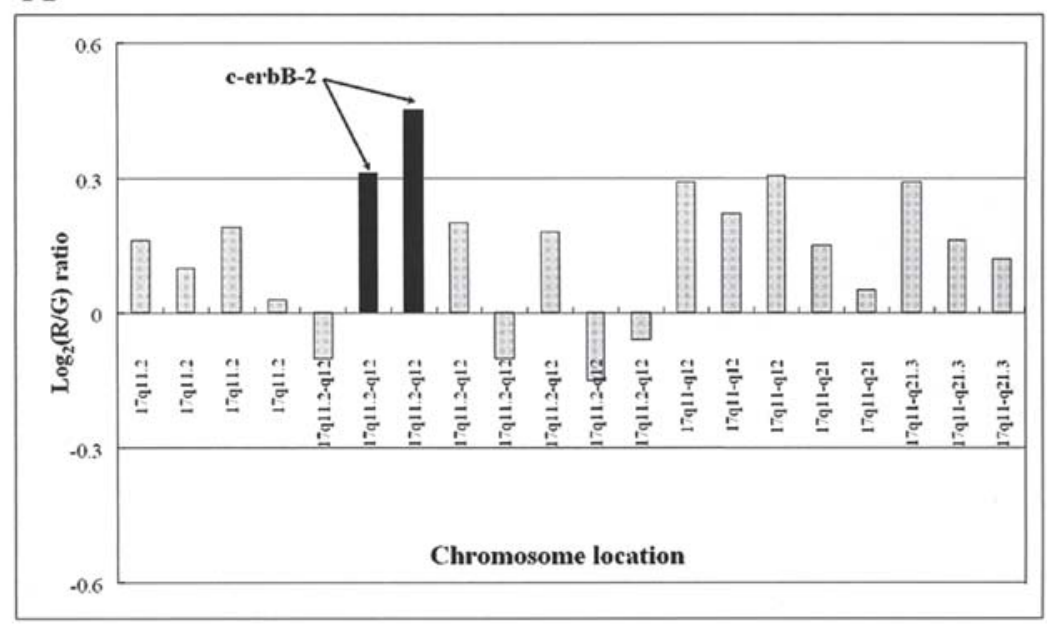

B

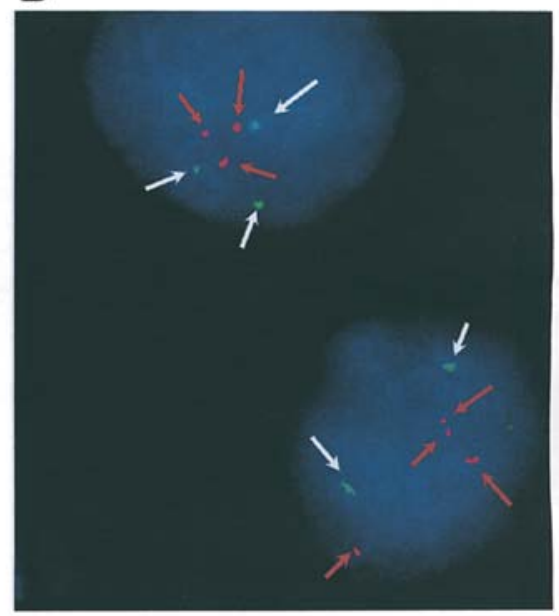

Figure 4. Microarray-CGH result and FISH analysis in 17 chromosome. (A) Distribution of 17q11.2-17q21.3 located 20 genes with Microarray-CGH. Two clones with c-erbB-2 gene showed a genetic alteration patterns. (B) FISH analysis with 17 chromosome and c-erbB-2 gene. Several cells showed a 17 trisomy genomic alteration and other cells showed a no genomic change. c-erbB-2 genes showed a $1.5-2\left(0.3-0.68 \log _{2}\right.$ ratio) copies genetic amplification patterns; black columns, c-erbB-2 clones; grey columns, 17q11.2-17q21.3 located genes; white arrow, $\alpha$-satellite DNA probe for chromosome 17; red arrow, c-erbB-2 gene locus (17q11.2-q12).

Comparison of Microarray-CGH and FISH analysis in YCC-16 gastric cancer cells. In Microarray-CGH, YCC-16 gastric cancer cells showed a genomic alteration patterns in 17 chromosome. Twenty genes locating on 17q11.2-17q21.3 showed a normal genomic pattern except two clones of cerbB-2 gene (Fig. 4A). The amplified gene copy number change detected by Microarray-CGH was confirmed by FISH analysis (Fig. 4B).

\section{Discussion}

Generally, the direct design is an ideal platform for analyzing a genomic alteration in cancer. However, as the test samples are not always available paired normal tissues in other diseases, an indirect design is applied even if this system has the risk of a genomic disparity due to test organ differences. In the indirect design of $\mathrm{CGH}$, normal lymphocytes or placenta tissues have been used as a reference (7-11). This study determined the cut-off value for genomic alterations such as a gain, loss, amplification and deletion in the Microarray-CGH system using a normal placenta as a reference and normal gastric tissues as the test sample with sex-matched and -mismatched designs.

Several reports have described the advantage of DNA copy number change using a cDNA microarray with a high resolution with $0.5-2 \mathrm{~kb}$ length and a high sensitivity $(4,13)$. In previous studied reported that Microarray-CGH has a weak point with a $10-15 \%$ false positive rate on detection and amplification of single copy change genes in genomic DNA due to sensitivity and specificity of Microarray-CGH (4). Our cDNA microarray composed of a 0.5-2 kb length of cDNA which clones distributed a 50-100 kb length of genomic DNA. Theoretically, the $\log _{2}$ ratio of a one copy change of gene is 1 . However, this study obtained an absolute $0.68 \log _{2}$ ratio for the gene copy change. This difference between theoretical and experimental values might be due to technical issues as well as the different platforms used. First, an under- estimation of the $\mathrm{X}$ chromosome located genes might result from the cross-hybridization of the probe with an autosomal or Y chromosomal genes due to the strong homology to the target sequence of the $\mathrm{X}$ chromosomal genes (15). Second, a random fragmentation step for the genomic DNA processing produced fragments with different sizes in the same gene. This phenomenon might cause differences in the labeling efficiency, which might result in a fluorescence difference. Moreover, the fragmentation activity by the restriction enzyme of DpnII is blocked by CpG methylation (16), which also induces a variation in the fragmentation efficiency. Third, labeled genomic DNA fragments are hybridized to arrays made from the individual DNA fragments that have been cloned from a reduced sequence, i.e. not a full length sequence (17). Moreover, the reduced sequence of each gene increases the genomic homology with the other genes, which may finally cause an altered reproducibility of hybridization among the different institutions. Fourth, by definition, a gene amplification means that the whole sequence of the genes is duplicated, triplicated, or more. However, in biological situations, genomic changes occur as a sub-regional sequence insertion or a deletion of a gene. In some cases, the genomic alteration is caused by a point mutation, insertion and deletion, which might cause differences in the labeling and fluorescence signals. These types of experimental variations described above have different criteria in determining the genomic alteration in both the Microarray-CGH and conventional CGH.

And several genes showed a pseudo-alteration patterns, which might be related to the effect of the fluorescence such as a difference in the dye incorporation rate or the dye degradation rate. Even if some genes are closely located at the chromosome $6 \mathrm{q} 21$ and $19 \mathrm{q} 13.3$, the genes on $6 \mathrm{q} 21$ and $19 q 13.3$ showed a normal genomic aberration patterns.

Despite there being several sources of the experimental variations, the Microarray-CGH system developed in this study showed the systemic advantages and reproducibility. There 
was no difference of experiment patterns in the autosomal level even with the tissue differences used (gastric versus placenta) and the design differences such as direct versus indirect and sex-matched versus sex-mismatched.

Comparison of Microarray-CGH and FISH analysis validated our Microarray-CGH system as highly sensitive and specific system. Actually, the false positive rate in detecting an amplified or deleted gene change in our systems was $0.4-1 \%$, suggesting $99 \%$ specificity and reproducibility. These false positive genes might be caused by genetical variation with cDNA sequence homology and individual variation of sample and technical variations such as $0.1-0.2 \%$ batch variation or a difference in the restriction enzyme activity. When we investigated the false positive genes, 2/3 of the false positive genes showed sequence homology genes in different chromosomes and 1/10 showed sequence homology genes in the same chromosome (data not shown).

In conclusion, from systemic analysis, $10.681 \log _{2}$ ratio was suggested as a criteria of genomic alterations such as duplicated or deleted gene changes regardless of difference in design (direct, indirect, sex-matched, or sex-mismatched).

\section{Acknowledgements}

This work was supported by the Korea Science and Engineering Fund to the Cancer Metastasis Research Center at Yonsei University.

\section{References}

1. Kallioniemi A, Kallioniemi OP, Sudar D, Rutovitz D, Gray JW, Waldman F and Pinkel D: Comparative genomic hybridization for molecular cytogenetic analysis of solid tumors. Science 258: 818-821, 1992.

2. Redon R, Hussenet T, Bour G, Caulee K, Jost B, Muller D, Abecassis $\mathrm{J}$ and Du Manoir S: Amplicon mapping and transcriptional analysis pinpoint cyclin $\mathrm{L}$ as a candidate oncogene in head and neck cancer. Cancer Res 62: 6211-6217, 2002.

3. Wilhelm M, Veltman JA, Olshen AB, Jain AN, Moore DH, Presti JC Jr, Kovacs G and Waldman FM: Array-based comparative genomic hybridization for the differential diagnosis of renal cell cancer. Cancer Res 62: 957-960, 2002.

4. Pollack JR, Perou CM, Alizadeh AA, Eisen MB, Pergamenschikov A, Williams CF, Jeffrey SS, Botstein D and Brown PO: Genomewide analysis of DNA copy-number changes using cDNA microarrays. Nat Genet 23: 41-46, 1999.

5. Squire JA, Pei J, Marrano P, Beheshti B, Bayani J, Lim G, Moldovan L and Zielenska M: High-resolution mapping of amplifications and deletions in pediatric osteosarcoma by use of CGH analysis of cDNA microarrays. Genes Chromosomes Cancer 38: 215-225, 2003.

6. Zhao J, Roth J, Bode-Lesniewska B, Pfaltz M, Heitz PU and Komminoth P: Combined comparative genomic hybridization and genomic microarray for detection of gene amplifications in pulmonary artery intimal sarcomas and adrenocortical tumors. Genes Chromosomes Cancer 34: 48-57, 2002.

7. Guan XY, Fu SB, Xia JC, Fang Y, Sham JS, Du BD, Zhou H, Lu S, Wang BQ, Lin YZ, Liang Q, Li XM, Du B, Ning XM, $\mathrm{Du}$ JR, Li P and Trent JM: Recurrent chromosome changes in 62 primary gastric carcinomas detected by comparative genomic hybridization. Cancer Genet Cytogenet 123: 27-34, 2000.

8. Ishizuka T, Tanabe C, Sakamoto H, Aoyagi K, Maekawa M, Matsukura N, Tokunaga A, Tajiri T, Yoshida T, Terada M and Sasaki H: Gene amplification profiling of esophageal squamous cell carcinomas by DNA array $\mathrm{CGH}$. Biochem Biophys Res Commun 296: 152-155, 2002.
9. Jain AN, Chin K, Borresen-Dale AL, Erikstein BK, Eynstein LP, Kaaresen R and Gray JW: Quantitative analysis of chromosomal $\mathrm{CGH}$ in human breast tumors associates copy number abnormalities with p53 status and patient survival. Proc Natl Acad Sci USA 98: 7952-7957, 2001.

10. Kong G, Oga A, Park CK, Kawauchi S, Furuya T and Sasaki K DNA sequence copy number aberrations associated with histological subtypes and DNA ploidy in gastric carcinoma. Jpn J Cancer Res 92: 740-747, 2001.

11. Varis A, van Rees B, Weterman M, Ristimaki A, Offerhaus J and Knuutila S: DNA copy number changes in young gastric cancer patients with special reference to chromosome 19 . Br J Cancer 88: 1914-1919, 2003.

12. Hedenfalk I, Ringner M, Ben-Dor A, Yakhini Z, Chen Y, Chebil G, Ach R, Loman N, Olsson H, Meltzer P, Borg A and Trent J: Molecular classification of familial non-BRCA1/BRCA2 breast cancer. Proc Natl Acad Sci USA 100: 2532-2537, 2003.

13. Seo MY, Rha SY, Yang SH, Kim SC, Lee GY, Park CH, Yang WI, Ahn JB, Park BW and Chung HC: The pattern of gene copy number changes in bilateral breast cancer surveyed by cDNA microarray-based comparative genomic hybridization. Int J Mol Med 13: 17-24, 2004.

14. Ulger C, Toruner GA, Alkan M, Mohammed M, Damani S, Kang J, Galante A, Aviv H, Soteropoulos P, Tolias PP, Schwalb MN and Dermody JJ: Comprehensive genome-wide comparison of DNA and RNA level scan using microarray technology for identification of candidate cancer-related genes in the HL-60 cell line. Cancer Genet Cytogenet 147: 28-35, 2003.

15. Fiegler H, Carr P, Douglas EJ, Burford DC, Hunt S, Scott CE, Smith J, Vetrie D, Gorman P and Tomlinson IP: DNA microarrays for comparative genomic hybridization based on DOPPCR amplification of BAC and PAC clones. Genes Chromosomes Cancer 36: 361-374, 2003.

16. Lacks S and Greenberg B: A deoxyribonuclease of Diplococcus pneumoniae specific for methylated DNA. J Biol Chem 250: 4060-4066, 1975

17. Albertson D, Dee S, Fan JB, Hirschhorn JN, Huang X, Iyer V, Lim YM, Lindblad-Toh K, Lucito R, Matsuzaki H, Patil N, Pinkel D, Pollack JR, Ryder T, Segraves R, Sklar P, Snijders A and Wigler M: Using Microarrays for Genomic Analysis. Bowtell D and Sambrook J (eds). New York, 2003.

18. Frolov A, Prowse AH, Vanderveer L, Bove B, Wu H and Godwin AK: DNA array-based method for detection of large rearrangements in the BRCA1 gene. Genes Chromosomes Cancer 35: 232-241, 2002.

19. Kim DW, Choi SJ, Lee JY, Kim KJ, Park MI, Park SJ, Koo SH and Koo JY: Genetic alterations in gastric carcinomas and adjacent mucosa detected by comparative genomic hybridization (CGH). Cancer Res Treat 33: 309-317, 2001.

20. Lucito R, West J, Reiner A, Alexander J, Esposito D, Mishra B, Powers S, Norton L and Wigler M: Detecting gene copy number fluctuations in tumor cells by microarray analysis of genomic representations. Genome Res 10: 1726-1736, 2000.

21. Nessling M, Solinas-Toldo S, Wilgenbus KK, Borchard F and Lichter P: Mapping of chromosomal imbalances in gastric adenocarcinoma revealed amplified protooncogenes MYCN, MET, WNT2, and ERBB2. Genes Chromosomes Cancer 23: 307-316, 1998.

22. Peng DF, Sugihara H, Mukaisho K, Tsubosa Y and Hattori T: Alterations of chromosomal copy number during progression of diffuse-type gastric carcinomas: metaphase- and array-based comparative genomic hybridization analyses of multiple samples from individual tumours. J Pathol 201: 439-450, 2003.

23. Pinkel D, Segraves R, Sudar D, Clark S, Poole I, Kowbel D, Collins C, Kuo WL, Chen C, Zhai Y, Dairkee SH, Ljung BM, Gray JW and Albertson DG: High resolution analysis of DNA copy number variation using comparative genomic hybridization to microarrays. Nat Genet 20: 207-211, 1998.

24. Weiss MM, Snijders AM, Kuipers EJ, Ylstra B, Pinkel D, Meuwissen SG, van Diest PJ, Albertson DG and Meijer GA: Determination of amplicon boundaries at 20q13.2 in tissue samples of human gastric adenocarcinomas by high-resolution microarray comparative genomic hybridization. J Pathol 200: 320-326, 2003. 